June 2018

\title{
Leaning Forward While Looking Back
}

Anthony Bernier

San Jose State University, anthony.bernier@sjsu.edu

Follow this and additional works at: https://scholarworks.sjsu.edu/ischoolsrj

Part of the Archival Science Commons, Cataloging and Metadata Commons, Collection Development and Management Commons, Information Literacy Commons, Scholarly Communication Commons, and the Scholarly Publishing Commons

\section{Acknowledgements}

We are pleased to offer special thanks for the vision and support of the following: Former Dean, Dr. Charlie Bullock; current Dean, Dr. Mary Schutten, emeritus faculty and former School Director, Dr. Ken Haycock; current Director, Dr. Sandra Hirsh; Associate Director, Dr. Linda Main; The entire full-time faculty (aka the Editorial Advisory Board); Berkeley's Electronic Press (bepress).

\section{Recommended Citation}

Bernier, A. (2018). Leaning Forward While Looking Back. School of Information Student Research Journal, 8(1). https://doi.org/10.31979/2575-2499.080104 Retrieved from https://scholarworks.sjsu.edu/ ischoolsrj/vol8/iss $1 / 4$

This article is brought to you by the open access Journals at SJSU ScholarWorks. It has been accepted for inclusion in School of Information Student Research Journal by an authorized administrator of SJSU ScholarWorks. For more information, please contact scholarworks@sjsu.edu. 


\section{Leaning Forward While Looking Back}

\section{Keywords}

iSchool, SRJ, SJSU, journal

\section{Acknowledgements}

We are pleased to offer special thanks for the vision and support of the following: Former Dean, Dr. Charlie Bullock; current Dean, Dr. Mary Schutten, emeritus faculty and former School Director, Dr. Ken Haycock; current Director, Dr. Sandra Hirsh; Associate Director, Dr. Linda Main; The entire full-time faculty (aka the Editorial Advisory Board); Berkeley's Electronic Press (bepress).

\section{About Author}

Dr. Anthony Bernier is the faculty advisor of the SRJ and a professor at San Jose University's iSchool. 
It is not easy to publish a scholarly journal. One of the hallmarks of a successful journal, however, is the degree to which it can build and sustain community. It is clear that the Student Research Journal (SRJ) has achieved that.

In demonstrating its commitment to quality, and especially as we hit the $100,000^{\text {th }}$ article download milestone, the $S R J$ manifests its utility to both the mission and vision of our School of Information. In terms of the School's documented strategic objectives, the $S R J$ meaningfully "contributes to the education of information professionals who excel and contribute to the well-being of our global communities."

The SRJ also demonstrably contributes to the School's commitment to "leadership in graduate education and research in the information professions, delivering innovative, top quality programs." The $S R J$ remains SJSU's only student governed, double-blind peer reviewed, open-source venue for the dissemination of student research. The journal enhances this student experience through an engaging and exclusively online experience.

Operationally, the $S R J$ serves as a key performance indicator for elevating the iSchool's curricular quality in delivering true innovation. Most especially the journal fosters a research-oriented environment.

From its start in 2010, the $S R J$ has remained entirely student governed and committed to top quality performance. Indeed, overall, student editors tend to be even more discerning than academic peer reviewers. Since the beginning the SRJ maintains an acceptance rate of $21 \%$ which is competitive with most of the top quality peer reviewed journals anywhere in the academy.

As Faculty Advisor since the beginning, it has been my privilege to help institutionalize the journal's operations so that year after year quality team experiences thrive even within the limits of constantly graduating students and my direct interactions with years of student Editors-in-Chief number among some of the most satisfying in my experience as a faculty member at SJSU. I take particular pride in noting that many of our Editors-in-Chief and Managing Editors "promoted up" from other roles on the Editorial Team.

Since the opportunity to celebrate this milestone comes along only once, I hasten to acknowledge all our previous Editors-in-Chief here: our very first Editor-in-Chief, Suzanne Scott (2010-2011), Maria Otero-Boisvert, Stacey Nordlund, Elyse Meyers, Adrienne Mathewson, Tamarack Hockin, and our most recent past Chief, Holley Cornetto. It's also my pleasure to welcome on board our most recently appointed Editor-in-Chief, Megan Price. These talented people represent the "public face" of the $S R J$. They recruited and appointed Editorial Team members, supervised execution of an on-going strategic plan, reported regularly to the faculty (our Editorial Advisory Board), and, of course, hit that last button that says "publish."

Each of the people assuming the Chief's chair, however, know that publishing a journal, like any collective effort, requires an entire team. The Chiefs have run the organization well - an organization in which players play different positions but the team aims at one goal. And it has been through a remarkable succession of Managing Editors (all appointed by the Chief's themselves) that $S R J$ operations run as smoothly as they do: our first Managing Editor, Stacey 
Nordlund (2011), followed by Susan B. Wainscott, Barnaby Hughes, Sara Kelso, Janet Casey, Gina Nichols, Laurel A. Brenner, Lindsey Travis, and Kelly Pollard. Each of these talented managers distributed manuscripts, monitored editorial traffic, synthesized peer reviews, facilitated monthly ET meetings, trained new ET appointees, and developed additional journal enhancement projects along with their editors.

The SRJ's community extends beyond the Editorial Team, the Editorial Advisory Board, authors, and even its readers. Each year SJSU graduates who have served on the journal's Editorial Team gather to discuss recent changes, share and brainstorm new ideas, and make connections back to the $S R J$ and to SJSU. This is the SRJ Alumni Advisory Group. Many of our creative innovations have come from this community.

Beyond the milestone of 100,000 downloads, however, other important numbers deserve acknowledgement in celebrating the SRJ's achievements. Since we began in 2010, Editors-in-Chief made approximately 128 Editorial Team appointments. Many ET members, living all over the world - as our students do served more than one term. This number of course does not count the many hundreds more students who expressed sufficient interest in applying for appointment.

SRJ Editorial Teams peer reviewed, evaluated, commented upon, and improved hundreds of manuscripts yielding 80 original graduate student articles contributing to the development of our field. Many submissions originated in LIS programs other than SJSU. These figures do not count the additional hundreds of students who submitted manuscripts.

In addition, aside from the $100,000^{\text {th }}$ download, $S R J$ articles have been read in 189 different countries.

Just as looking back enlivens a celebration so does a lean forward anticipate the future. The $S R J$ certainly anticipates future success. The journal not long ago expanded the opportunity for students to publish scholarly book reviews. And the ET is on the verge of introducing "Evidence Summaries," a newer form of scholarly communication initially advanced by SRJ Alumni, and inspired by one of the best scholarly journals in our field, Evidence Based Library and Information Practice. Both of these new opportunities offer graduate students additional ways to establish a voice in professional leadership by evaluating new work while still pursuing their master's degree.

The SRJ, now more than ever, is also reaching out beyond SJSU. Our future marketing and promotion plans promise to systematically solicit more manuscripts from other LIS programs and we are inviting Editorial Team applications from other LIS programs as well. We are even preparing to reach out to faculty from other schools as potential invited contributors.

Thus, in looking back over these initial years of achievement it is clear that the $S R J$ has established itself as a key success indicator for promoting scholarly community and broadening the School's research profile. Benefits flow in all directions:

- $\quad$ to and from ET members; 
- to students from all over who contribute to the journal through submitting manuscripts;

- to students who benefit from the resources the ET produces to enhance scholarly communication;

- to and from the faculty who both recommend student manuscripts for publication and those who use $S R J$ articles in their courses;

- to the School of Information, the College of Applied Sciences and Arts (CASA), and to the University as a whole in terms of representing outstanding small group achievement in an exclusively distance-oriented graduate program.

Finally, I'd like to say that the success and growth of the Student Research Journal numbers among my own proudest contributions to the School. The community we are creating together leaves a legacy in which we can all take pride. 